\title{
O NOUĂ ABORDARE A ASISTENȚEI SOCIALE DE SPITAL
}

\section{Claudia Viorica BARBUL* Adriana Forentina CĂLĂUZ ${ }^{* * *}$}

A New Approach to Hospital Social Work

\begin{abstract}
The profession of social worker in the emergency departments represents a new direction of development of the social assistance services in the field of health care. Currently, more and more studies emphasize the need to integrate medical and psychosocial care, suggesting that health systems could better manage patients' medical problems if they also addressed their psychosocial problems. However, studies are relatively few, which is why future research is essential to support the value of social work in healthcare teams. Our research is based on studies performed within the Emergency Receiving Unit (UPU-SMURD) of the County Hospital "Dr. Constantin Opriss" in Baia Mare. The present study draws an overview of the types of social problems that accompany and influence the health problems of the population served in this service, and facilitates the precise definition of the problems, in order to carry out the steps to find suitable solutions.
\end{abstract}

Keywords: Medical Social Worker, Mental Health Practitioner, Emergency Reception Unit

\section{Introducere}

Asistența socială din departamentele de urgență se constituie ca o profesie nouă cu perspective promiţătoare de dezvoltare, susținută puternic de dovezile beneficiilor pe care le aduce comunităţii și structurilor organizaționale pe care le deservește.

În România, postul de asistent social în serviciile medicale de urgenţă a fost prevăzut pentru prima dată în Ordinul MS 1706/2008.

Deși au trecut deja 10 ani de la cooptarea asistenților sociali în echipele multidisciplinare din departamentele de urgență, în țara noastră, încă nu există studii și cercetări care să fundamenteze rolurile asistentului social în cadrul structurilor organizaționale specifice medicinei de urgență, tipologia problemelor specifice acestor departamente care solicită expertiza asistentului social, avantajele pe care asistentul social din departamentele de urgență poate să le ofere.

\footnotetext{
Social worker within the Emergency Receiving Unit (UPU-SMURD) of the County Hospital "Dr. Constantin Opriș", Baia Mare.

** Lecturer PhD., Technical University of Cluj-Napoca, University Center of Baia Mare, Specialization - Social Work, 76 Victoriei Street, Baia Mare (adrianacalauz@yahoo.com).
} 
Rezultatele cercetărilor actuale, efectuate în țări care au sisteme de sănătate cu tradiție în ceea ce privește serviciile de asistență socială în departamentele de urgență, aduc dovezi convingătoare referitoare la beneficiile pe care asistentul social le furnizează în cadrul echipelor multidisciplinare a acestor servicii.

Astfel am făcut un studiu care să evidenţieze beneficiile pe care asistentul social le furnizează în cadrul echipelor multidisciplinare a acestor servicii.

\section{Medical Social Worker}

Medical social worker (MSW) este o subdisciplină a asistenței sociale cunoscută și sub numele de asistență socială in spital sau asistență socială in serviciile de ingrijire. Medical social worker sunt absolvenți cu diplomă de licență sau postuniversitară, specializaţi să lucreze cu pacienţii și familiile acestora, atunci când aceștia se confruntă cu diverse bariere psihosociale.

Asistenții sociali din domeniul medical lucrează într-o varietate de echipe incluzând staționare medico-chirurgicale, secții de cardiologie, oncologie, nefrologie, servicii de îngrijiri la domiciliu, hospice, Unitati de primire Urgente (UPU), secții de pediatrie și obstetrică.

Ida Cannon (1923), sublinia că misiunea MSW este aceea de a căuta să elimine, acele obstacolele care aparțin bolnavului și atitudinii lui mentale, obstacole care interferează cu succesul tratamentului medical și împiedică recuperarea pacientului ${ }^{1}$

MSW oferă intervenții pentru spijinirea pacienților și a familiilor acestora pe tot parcursul recuperării sau ajustării lor la boală. Ei oferă sprijin psihosocial, management de caz, psihoeducație, consiliere, referire spre alte servicii. MSW pot performa și în diferite roluri administrative ale serviciilor de îngrijire cum ar fi: planificarea programelor de lucru sau ca legătură între organizația din care fac parte și mass-media.

Asistență socială de spital este un loc de muncă exigent și vulnerabil la impactul negativ al mediului. Este o profesie care necesită multă toleranță, atât datorită activităților sale specifice cât și naturii transdepartamentale cu nursingul și relațiilor cu publicul care diminuează vizibilitatea și gradul de autoritate a acestor profesioniști în cadrul institutiiilor ${ }^{2}$.

MSW rezolvă cazuri diverse care implică lipsa de adăpost, lipsa de

\footnotetext{
${ }^{1}$ Anderson Eric Sorem, Lippert Suzanne,Newberry Jennifer (2016)- Adressing the Social Determinants of Health from Emergency Department, Western Journal of Emergency Department, Martie 2016;

${ }^{2}$ Belea, Simion, (2014) The right to non-discrimination and equality of chances between women and men. în Buletin Ştiinţific. Fascicula Filologie. Seria A, vol. XXIII/ Baia Mare 2014, Editura U. T. Press Cluj-Napoca, p. 363-375, ISSN 1583 - 1264,
} 
venituri, lipsa de acoperire cu asigurări de sănătate, beneficiari cu antecedente de privare de libertate și/sau probleme de abuz și consum de droguri.

\section{Asistența socială în departamentele de urgență}

Asistența socială din departamentele de urgenţă constituie o subramura a asistenței sociale de spital, profesioniștii din acest domeniu îndeplinind toate functiile unui MSW.

Asistența socială din serviciile de urgență se deosebește de alte activități de asistență socială prin viteză, intensitate și necesitatea de a lucra în echipă.

În Anglia, țară care a constituit un model în organizarea sistemului românesc de medicină de urgență, asistența socială din cadrul Departamentelor de Urgență s-a dezvoltat ca răspuns la politicile de a evita internarea în spital a cazurilor nonacute, pentru a decongestiona aceste servicii și a reduce întârzierea externărilor pentru motive sociale. Bazele practicii asistenței sociale în Departmentele de Urgență din Anglia sunt bine definite și aproape toate departamentele de urgență au asistenți sociali specializați ${ }^{3}$.

Departamentul social al serviciilor de urgență, se constituie ca un punct cheie de acces către serviciile sociale, atât pentru pacienți cât și pentru îngrijitorii lor, având o importanță crucială pentru sănătatea și bunăstarea acestora.

Venirea în UPU reflectă adesea o criză, atât a pacienților cât și a aparținătorilor lor.

Pentru a-şi putea desfășura cu succes munca în cadrul unui departament de urgență asistentul social trebuie să aibă o înțelegere clară a ceea ce se întâmplă pacienților, trebuie să cunoască termenii medicali, anatomie și procedurile medicale și de asemenea să aibă capacitatea de a descifra limbajul medical și de a-1 traduce într-o terminologie uşor de înțeles. Ca și particularitate specifică, asistentul social din cadrul serviciului de urgență, are un set unic de calificări care se adresează pacientului și mediului acestuia și care sunt substanţial diferite de cele din modelul medical.

Formarea sa profesională îi permite să efectueze evaluări rapide și precise privind personalitatea individului ceea ce îl ajută să stabilească rapid raportul cu pacientul sau familia acestuia, să valideze sau să provoace comportamente, să furnizeze consiliere și să angajeze pacienții și familiile

\footnotetext{
${ }^{3}$ Wrenn K, Rice N (1994)- Social-work Services in an Emergency Department: An Integral Part of the Health Care Safety Net, Academic Emergency Medicine, Volume1, Pages 247253;
} 
lor în actul terapeutic.

De asemenea poate să efectueze evaluări comprehensive psihosociale care vizează: suportul social, unele situații de viață, statusul financiar, statutul de asigurat medical, nevoile spirituale sau religioase, consumul de alcool și droguri, obstacolele la externare, îndeplinirea criteriilor şi oportunităţile privind îngrijirea specializată.

De asemenea pot să furnizeze, consiliere de criză, referiri la serviciile de protecție pentru copii și adulți, referiri pentru servicii de îngrijire la domiciliu, pot efectua screening-ul distresului precum și scurte intervenții psihoterapeutice pentru reducerea anxietății sau pentru situațiile de consum de alcool și droguri ${ }^{4}$.

$\mathrm{Nu}$ în ultimul rând, ei pot furniza suport emoțional staff-ului medical, alături de care își desfășoară activitatea.

$\mathrm{Cu}$ toate acestea rolul asistenților sociali din departamentele de urgență este adesea subevaluat și de obicei sunt prima categorie profesională afectată de reducerile de personal.

\section{Rolul asistentului social din UPU în creșterea satisfacției pacienților}

Satisfacția pacienților referitoare la experiența lor în UPU, este afectată semnificativ de calitatea comunicării cu staff-ul medical şi îngrijirea personală pe care pacienții au primit-o.

Un studiu efectuat de Serano și colab pe 600 pacienți dintre care $1 / 2$ au fost supravegheați de un asistent social și $1 / 2$ nu, relevă că $1 / 3$ dintre pacienții care au venit în contact cu asistentul social, au evaluat semnificativ mai pozitiv nu numai îngrijirea psihosocială, dar de asemenea şi calitatea îngrijirii medicale. Acest studiu reflectă experiența din UK a serviciilor de asistență socială în departamentele de urgență unde asistentul social, acționează ca suport pentru pacient și consilier pentru personalul medical în decizii de tratament dificile.

Realizând rolul de persoană de legătură între utilizatori și personalul serviciului, asistentul social din departamentele de urgență acționează în interesul ambelor părți. Pe de o parte ține utilizatorii informaţi despre deciziile cheie privind îngrijirea lor și pe de alta parte scade presiunea existentă asupra personalului medical datorită multitudinii de sarcini pe care le presupune activitatea de îngrijire a pacienților ${ }^{5}$.

\footnotetext{
${ }^{4}$ Moore L, Deehan A, Seed P, Jones R.- Characteristics of frequent attenders in an emergency department: analysis of 1 year attendance data. Emerg Med J. 2009; 26:263-7 National Association of Social Worker (2004) www.naswdc.org/practice

${ }^{5}$ Gordon JA.- Cost-benefit analysis of social work services in the emergency department: a conceptual model. Acad Emerg Med. 2001 Jan; 8(1):54-60;
} 


\section{Rolul asistentului social din UPU ca Mental Health Practitioner}

Un rol pe care asistenţii sociali cu specializare în psihologie pot să îl îndeplinească, este acela de a face evaluări referitoare la statusul sănătății mentale a pacienților.

Dziegielewski (1998) arată că asistenții sociali din echipele medicale ghidează procesele de evaluare clinică urmărind: angajarea pacienților în procesul de intervenție, conștientizarea acestora referitor la diferitele metode folosite în procesul de intervenție, identificarea și abordarea culturală, identificarea punctelor forte și a surselor de suport a pacienților. Specializarea în psihologie clinică, permite asistenților sociali să poată diagnostica tulburări psihice și de asemenea să ofere evaluări psihosociale pacienților și să stabilească serviciile pe care aceștia le pot primi ${ }^{6}$.

\section{Studiu privind analiza activității asistentului social din Unitatea Primiri Urgențe Baia Mare}

Ca obiective, ne-am propus, diagnoza problemelor sociale ale comunității pe care UPU-SMURD Baia Mare o deservește în vederea realizării demersurilor pentru găsirea unor soluții adecvate. Studiul documentelor elaborate de către asistenții sociali în cursul activității lor, ne-a ajutat in studiul nostru deoarece ea creionează o imagine de ansamblu a tipurilor de probleme sociale care acompaniază și influenţează problemele de sănătate a populației deservite, precum şi a tipului de persoane cel mai susceptibil de a fi afectate de astfel de probleme.

\section{Metodologie}

Analiza documentelor elaborate de asistentul social în cursul activității sale, ne-a oferit o serie de prevalențe privind problemele majore ale beneficiarilor de îngrijiri de sănătate din cadrul serviciilor de urgență.

Pentru prezentul studiu au fost analizate fișele de lucru elaborate și utilizate de asistenții sociali din cadrul UPU Baia Mare.

Analiza a luat în considerare documentele elaborate în cadrul compartimentului de asistență socială a serviciului mai sus amintit în perioada 01.01.2017-.31.03.2017.

Pentru realizarea acestui studiu au fost analizate:

- Registrul de evidenţă a cazurilor care au necesitat intervenţia asistentului social;

- Fișele de informare a aparţinătorilor și pacienților din cadrul UPU Baia Mare;

- Fișele de lucru ale asistenților sociali;

Dziegielewski, S. (1998) - The changing face of health care social work: professional practice in the end of managed care. New York, NY. Springer Publishing Company; 
- Fișele de raportare a urgențelor cauzate de intoxicații cu substanțe psihoactive;

- Fișele de lucru pentru gravidele care se prezintă în UPU în vederea nașterii fără acte de identitate sau cu acte de identitate expirate (H.G 1103/2014);

- Registrul electronic al înregistrărilor pacienților din UPU;

\section{Rezultatele studiului}

Analiza înregistrărilor electronice a pacienților, a fișelor de informare a pacienților și a aparținătorilor și analiza registrului de evidență a cazurilor a asistentului social, relevă că în perioada luată considerare pentru acest studiu, în UPU Baia Mare au fost consultați și au primit îngrijiri medicale 20.990 pacienți. Dintre aceștia $18.450(88 \%)$ au fost însoțiți de membrii familiei. Toți pacienții și membrii familiilor acestora au beneficiat de informații și ghidaj din partea asistentului social.

În perioada mai sus menționată asistenții sociali din UPU au fost efectuat 43 referiri către serviciile de asistență socială a diferitelor primării din județ prin care au atenționat asupra unor situații de risc social sau probleme sociale care implicau persoane adulte, venite ca și pacienți în serviciul nostru.

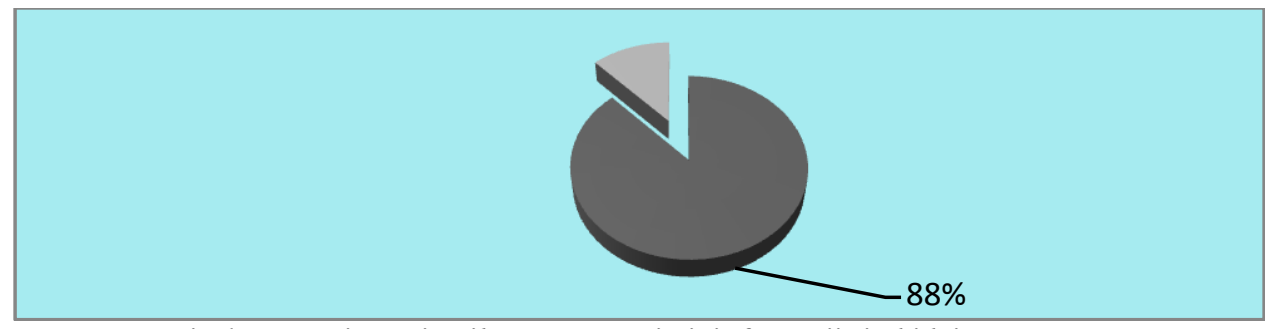

Fig.1 Proporția pacienților care au primit informații și ghidaj

Grupul celor pentru care s-au întocmit astfel de sesizări a inclus 22 de bărbați și 21 femei.

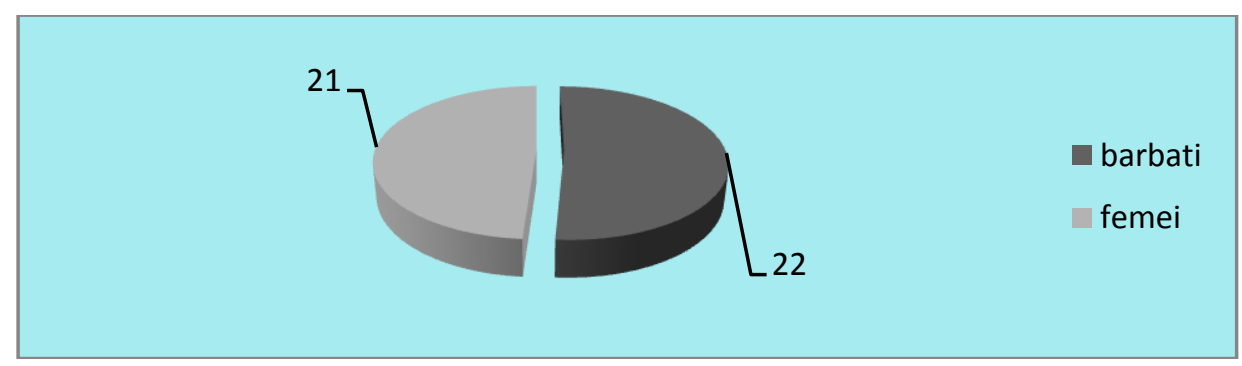

Fig. 2.Repartiția în funcție de sex a pacienților pentru care s-au făcut referiri la serviciile de asistență socială 
Pacienții de sex masculin din acest grup au avut vârste cuprinse între 26 și 80 de ani și cei mai mulți au aparținut palierului de vârstă 61-70 de ani.

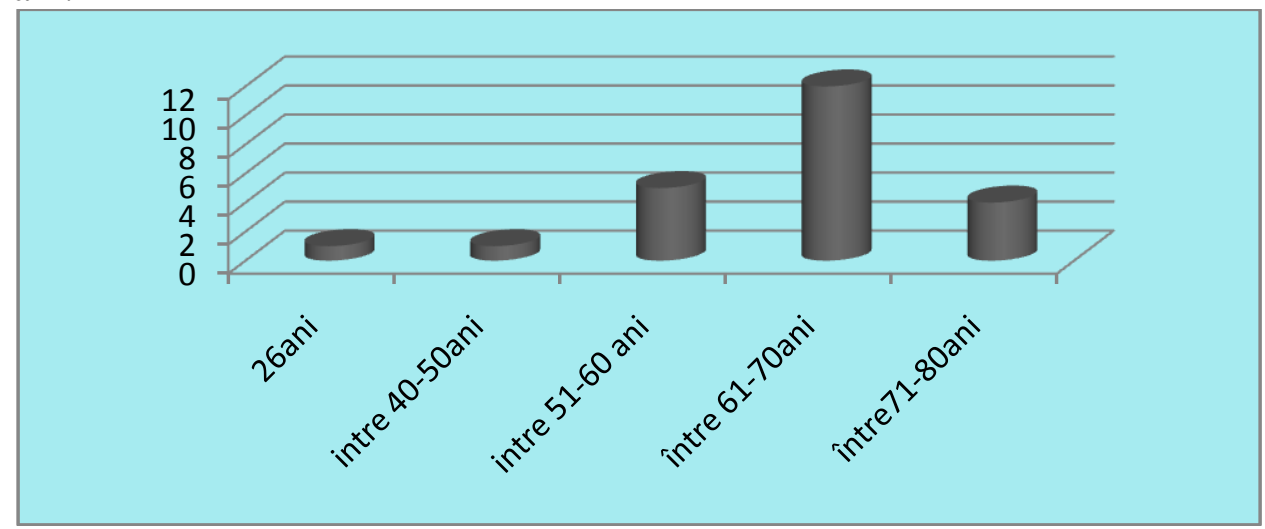

Fig. 3 Repartiția în funcție de vârstă a bărbaților pentru care s-au făcut referiri la seviciile de asistență socială

Un număr de 14 dintre ei erau cunoscuți ca persoane fără adăpost iar 8 locuiau singuri în condiții improprii, aveau suport social redus și sufereau de boli cronice extrem de grave.

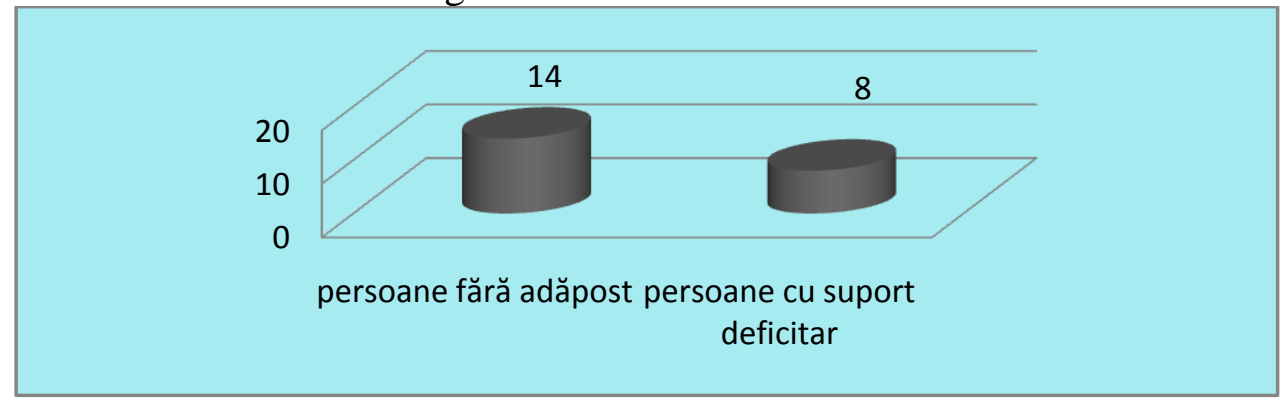

Fig. 4 Repartiția eșantionului de bărbați în funcție de problemele sociale identificate

În ceea ce privește grupul femeilor care au fost identificate ca și necesitând măsuri de intervenție socială, 10 dintre ele aveau peste 60 de ani, 4 sunt cunoscute ca fiind potatoare cronice și persoane fără adăpost, 4 au prezentat demență și suport social deficitar, 5 au fost victime ale violenței domestice și restul de 8 locuiau singure, sufereau de boli grave și aveau un suport social deficitar. 


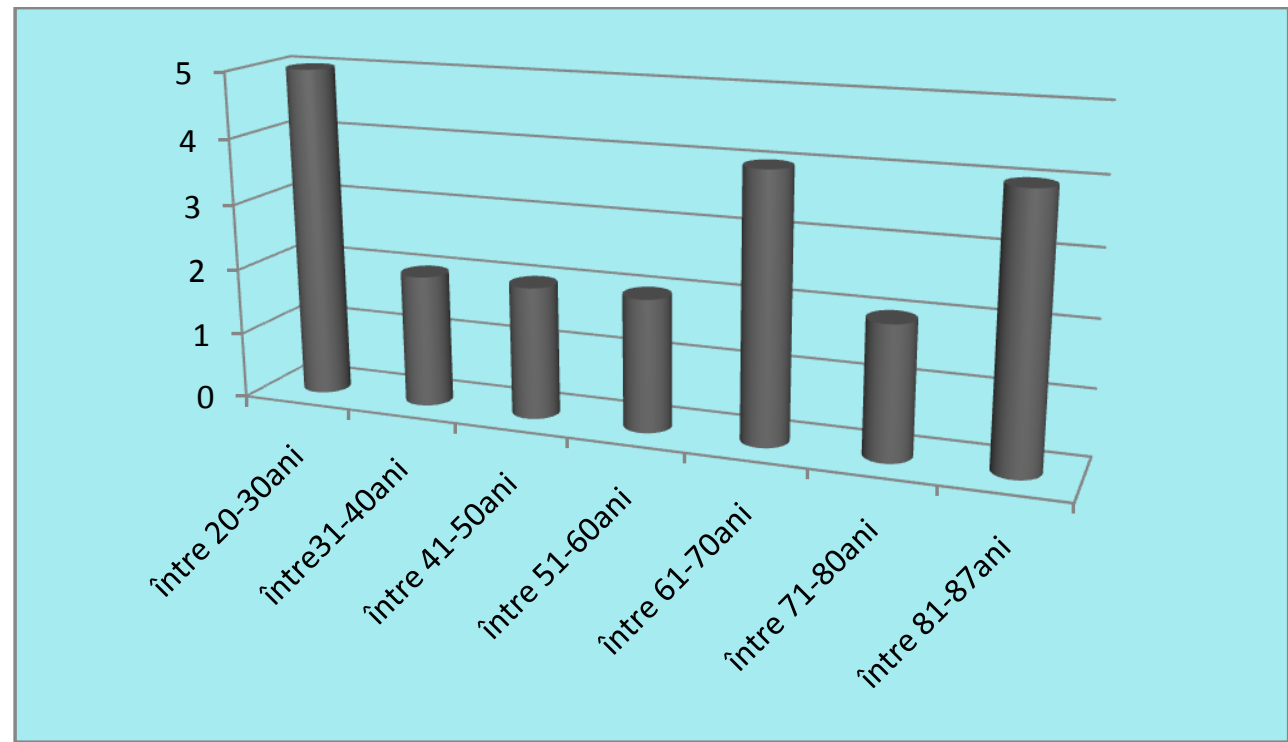

Fig 5. Repartiția în funcție de vârstă a femeilor pentru care s-au făcut referiri la serviciile de asistență socială

În ceea ce privește grupul femeilor care au fost identificate ca și necesitând măsuri de intervenție socială, 10 dintre ele aveau peste 60 de ani, 4 sunt cunoscute în serviciul nostru ca fiind potatoare cronice și persoane fără adăpost, 4 au prezentat demență și suport social deficitar, 5 au fost victime ale violenței domestice și restul de 8 locuiau singure, sufereau de boli grave și aveau un suport social deficitar.

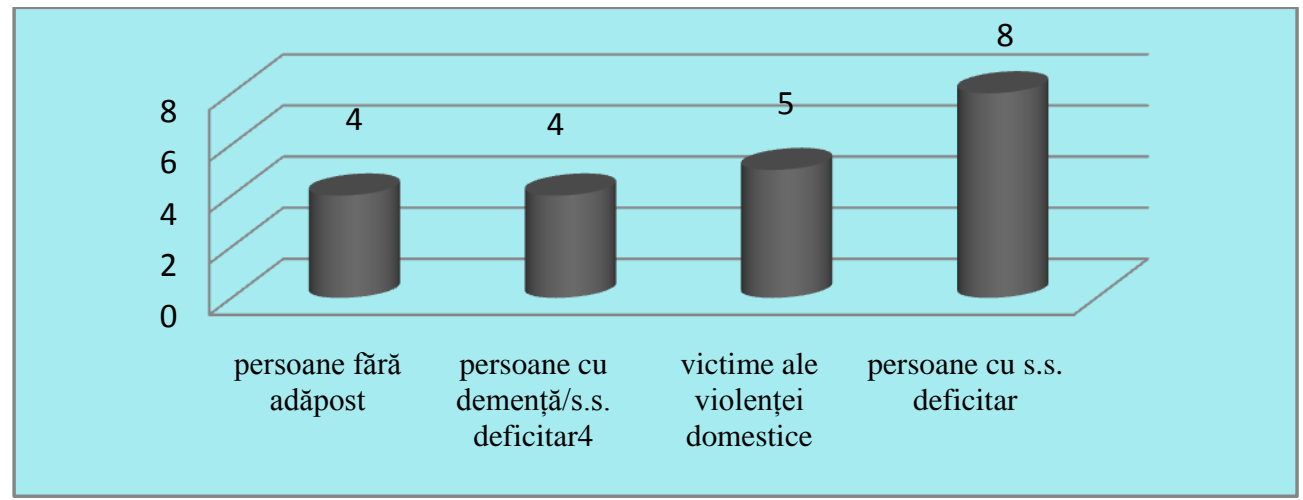

Fig.6. Repartiția eșantionului de femei în funcție de problemele sociale identificate

Totodată în perioada ianuarie-martie a.c. au fost făcute 60 de referiri la Adăpostul de Noapte, pentru un număr de 14 bărbăţi și 4 femei. Toate aceste persoane întruneau criteriile definiției persoanelor fără adăpost din Legea 292/2011. Bărbații pentru care s-au făcut astfel de referiri au avut vârste cuprinse între 26 și 75 ani, cei mai mulți aparţinând palierului 51-60 ani. Toți sunt consumatori de alcool în stadiu cronic, fără ocupație, nu întrețin legături cu familiile lor și de cele mai multe sunt aduși în UPU: cu 
ambulanța, fără acte de identitate prezentând o igienă extrem de deficitară și stare avansată de ebrietate.

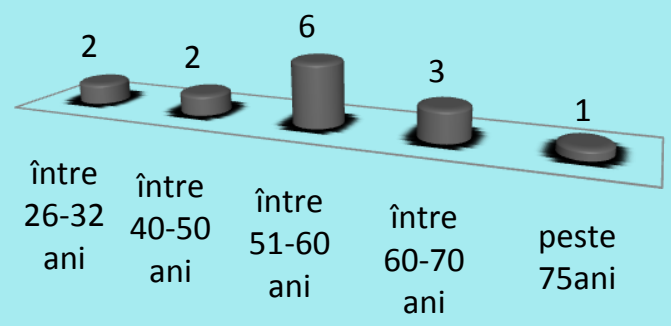

Fig.7 Repartitia persoanelor de sex masculin fără adăpost în functie de vârstă

În ceea ce privesc femeile, 3 dintre ele au vârsta mai mare de 50 de ani, toate sunt consumatoare cronice de alcool și au relații tensionate cu familiile lor.

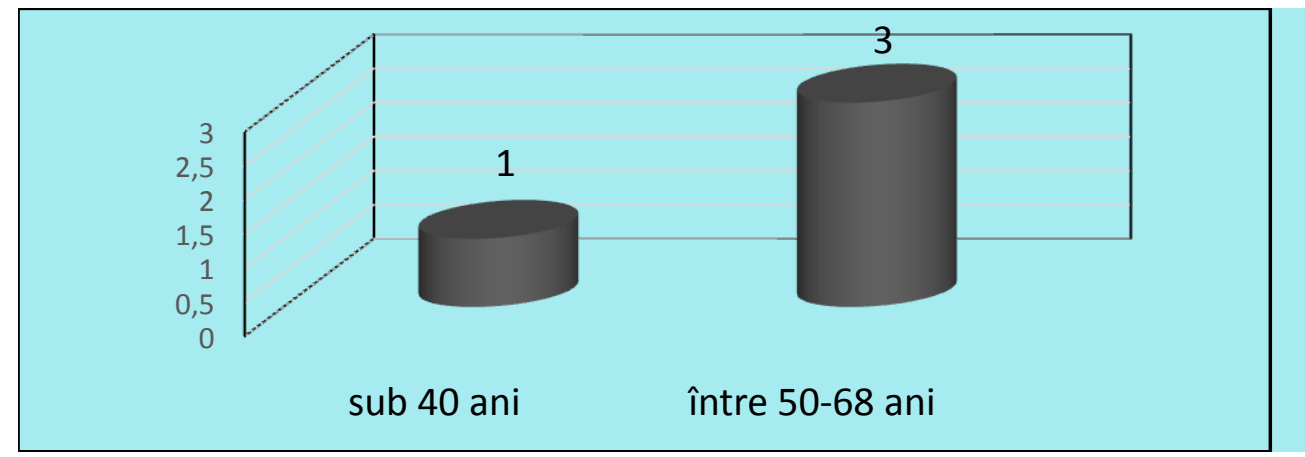

Fig.8 Repartiția persoanelor fără adăpost de sex feminin în funcție de vârstă

În aceeași perioadă au fost făcute 25 referiri către DGASPC. Copiii pentru care s-au făcut astfel de referiri au vârste cuprinse între 2 luni și 17 ani. Palierul de vârstă pentru care s-au făcut cele mai multe sesizări este cel de 13-17 ani. La ambele sexe problemele semnalate au vizat suspiciuni de neglijare și abuz, în special probleme suport social inadecvat, consum de substanțe psihoactive și probleme de comportament. 


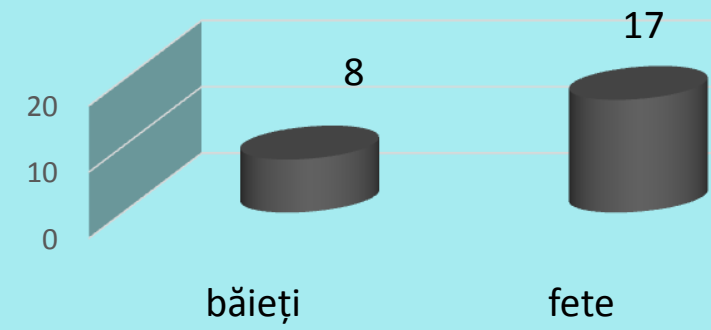

Fig.9 Repartiția în funcție de sex a copiilor pentru care s-au făcut sesizări la DGASPC

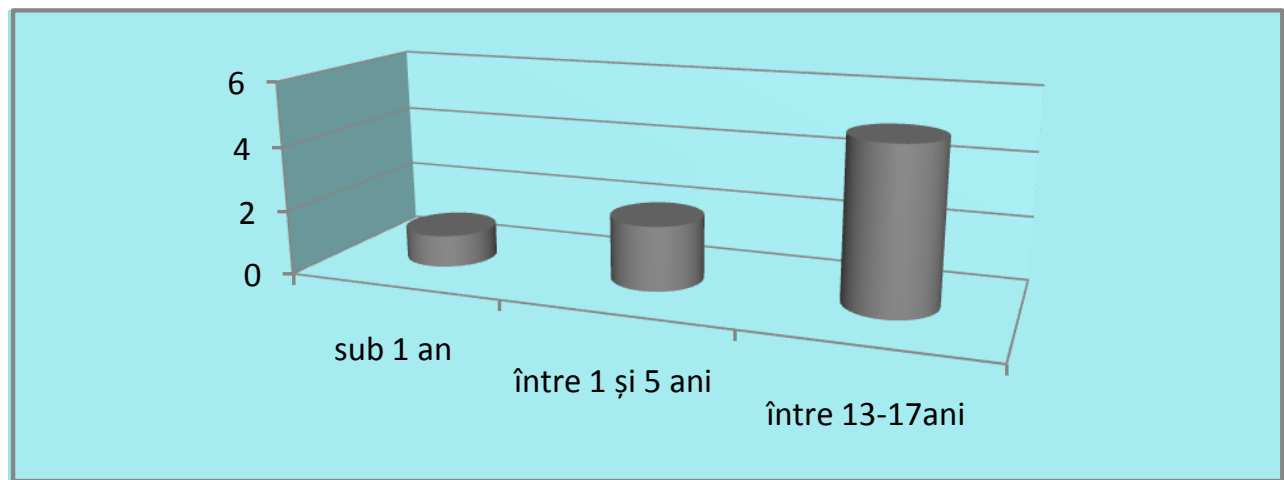

Fig.10 Repartiția în funcție de vârstă a băieților pentru care s-au făcut referiri la DGASPC

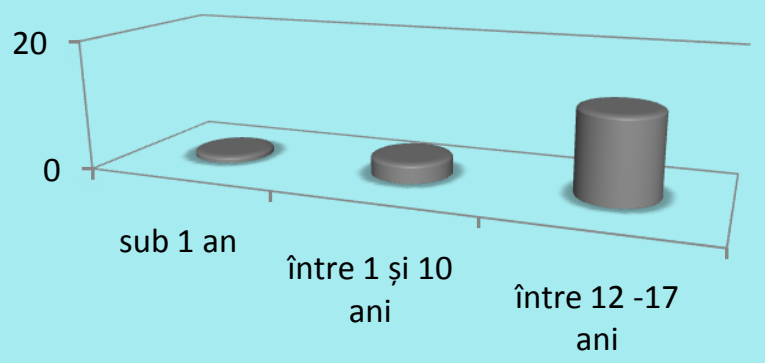

Fig.11 Repartiția în funcție de vârstă a fetelor pentru care s-au făcut referiri la DGASPC

De asemenea în perioada mai sus menţionată au fost efectuate 19 referiri la Agenția Națională Antidrog pentru consum de substanțe psihedelice. În majoritatea cazurilor s-au constatat intoxicaţii $\mathrm{cu}$ etnobotanice administrate prin inhalare (fumat).

A fost vorba de 13 persoane de sex masculin și 6 persoane de sex feminin cu vârste cuprinse între 15 și 29 de ani. 
13

20

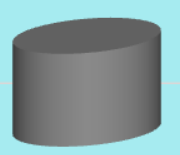

băieți
6

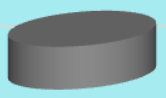

fete

Fig.12 Repartiția în funcție de sex a pacienților înregistrați în UPU în perioada ianuarie-martie 2017 cu intoxicații cu substanțe psihedelice

Cei mai mulți consumatori de sex masculin au avut vârste cuprinse între 21 și 29 de ani, pe când la consumatorii de sex feminin cei mai mulți au avut vârste cuprinse între 15 și 20 de ani.

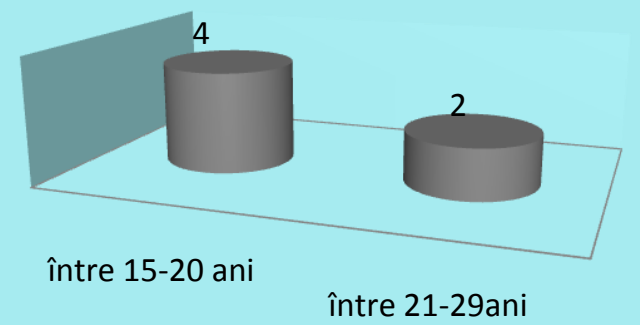

Fig.13 Repartiția în funcție de vârstă a pacienților de sex feminin înregistrați în UPU în perioada ianuarie-martie 2017 cu intoxicații cu substanțe psihedelice

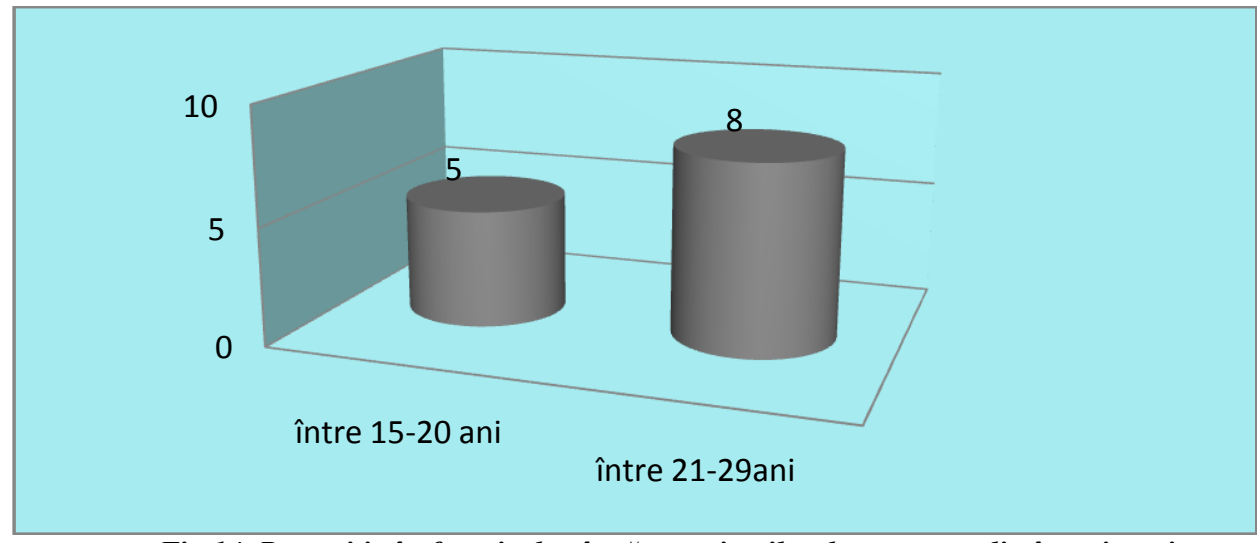

Fig.14 Repartiția în funcție de vârstă a pacienților de sex masculin înregistrați în UPU în perioada ianuarie-martie 2017 cu intoxicații cu substanțe psihedelice

De asemenea au fost efectuate 30 de consilieri de doliu pentru aparținători ale căror rudenii au decedat în UPU și 100 consilieri de criză ca urmare a unor situații amenințătoare de viață dintre care 57 ca urmare a 
unor accidente de circulație și 43 pentru condiții medicale extrem de grave .

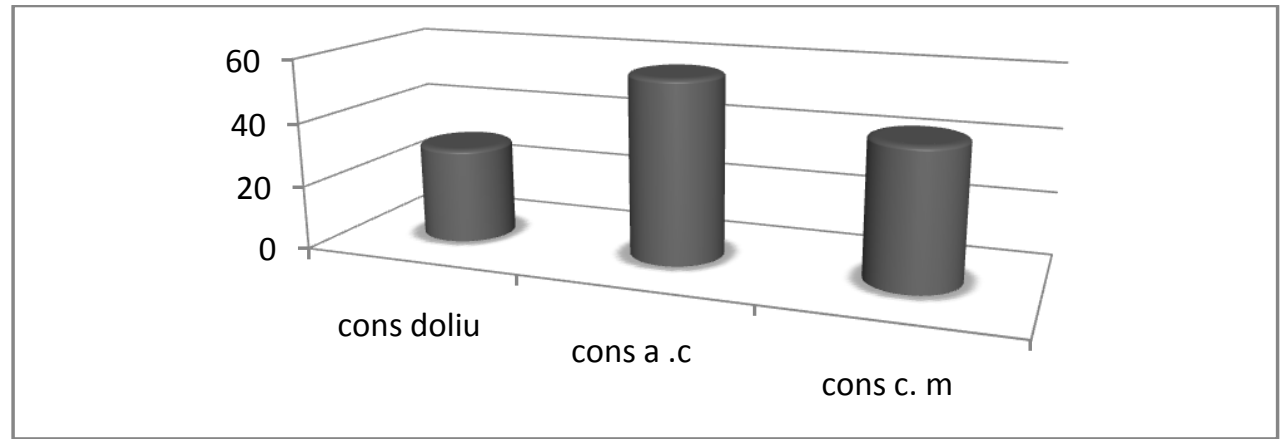

Fig.15 Distribuția cauzelor pentru care a fost necesară consilierea de criză în UPU în perioada ianuarie-martie 2017

Totodată s-a efectuat identificarea conform HG 1103/2014 pentru 4 gravide care s-au internat în vederea nașterii în Spitalul Județean de Urgență „Dr. Constantin Opriș”Baia Mare

Acestea au avut vârste cuprinse între 18 și 23 de ani. Una nu a deținut niciodată carte de identitate, 2 și-au pierdut-o și una avea CI expirată.

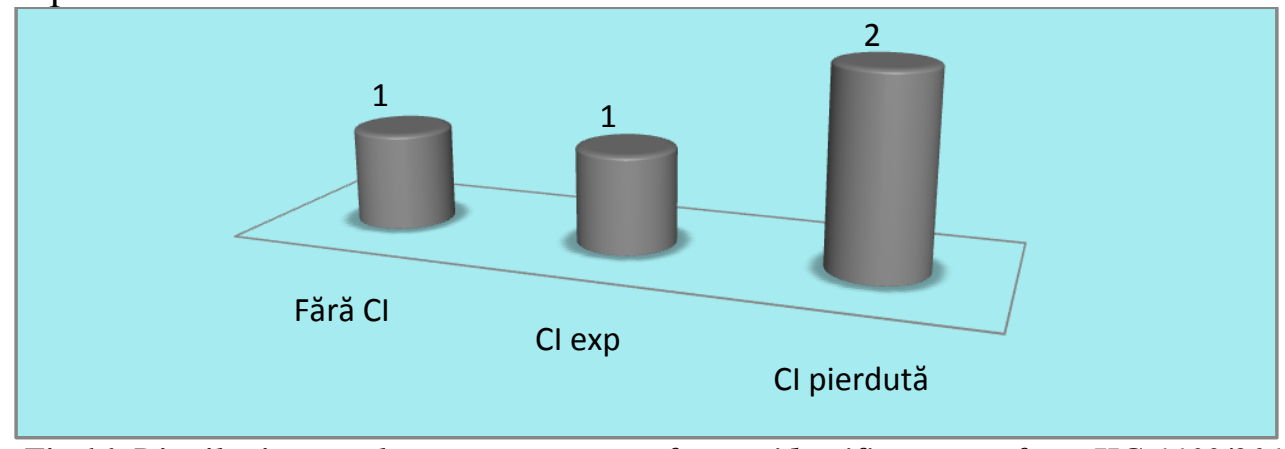

Fig.16. Distribuția cauzelor pentru care s-a efectuat identificarea conform HG 1103/201

De asemenea în perioada la care face referire studiul (01.01201731.03.2017), pentru 1024 de pacienți a fost necesară contactarea aparținătorilor pentru a se putea realiza externarea acestora în condiții de siguranță. Asta înseamnă că zilnic aproximativ 11 pacienți au avut nevoie de intervenția asistentului social în vederea externării lor în condiții de siguranță la domiciliu. Totodată datele indică că în perioada sus amintită 100 de pacienți au fost îndrumați spre societățile și organizațiile care prestează îngrijiri medicale la domiciliu și 20 de pacienți au fost consiliați vis a vis de întocmirea dosarului și procedurile de obținere a încadrării în grad de handicap.

Se poate observa că cei mai mulți pacienți care au avut nevoie de intervenția asistentului social pentru a fi referiți serviciilor de asistență socială ale primăriilor datorită situației de risc social în care se găseau, aparțin în cazul ambelor sexe palierului de vârstă peste 60 de ani, bărbații 
prezentând o susceptibilitate mai mare de a avea probleme de suport social, etanolodependență și de a ajunge în situația de persoane fără adăpost.

De asemenea, interviurile realizate acestor pacienţi, relevă că bărbații ajunși în astfel de situații au întrerupt orice legătură cu familiile lor, pe când în cazul femeilor, acestea de obicei menţin legătura cu familia chiar dacă relațiile sunt tensionate și nesatisfăcătoare.

Totodată analiza referirilor pentru servicii sociale efectuate de asistenții sociali din UPU Baia Mare, arată că femeile par a fi afectate de o paletă mai largă de probleme cu implicații sociale: condiții de deteriorare cognitivă, violența domestică, condiții precare de sănătate asociate cu suport social scăzut, dar cu toate acestea sunt semnificativ mai puţine cazurile în care au ajuns în situația de persoane fără adăpost, comparativ cu bărbații.

Consumul cronic de alcool este un predictor semnificativ pentru situația de a ajunge persoană fără adăpost.

În ceea ce privește analiza referirilor efectuate pentru copii de către asistenții sociali din cadrul acestui serviciu, se observă că vârsta care ridică cele mai multe probleme atât pentru fete cât și pentru băieți este cea a adolescenței, respectiv 13-17 ani. S-a constatat o frecvență mai mare a problemelor la fete. Situațiile referite au vizat: suspiciuni de neglijare sau abuz în special probleme de suport parental și suport social deficitar, consum de substanțe psihedelice și probleme de comportament

În ceea ce privește consumul de substanțe psihedelice în Baia Mare în perioada la care face referire acest studiu, se poate observa că conform documentelor elaborate de asistenții sociali din UPU, pare să fie o problemă care afectează exclusiv populația tânără, consumatorii care au avut nevoie de îngrijiri medicale, în cazul ambelor sexe având vârste cuprinse între 15 și 29 de ani. Numărul băieților care au fost aduși în UPU pentru astfel de probleme, este dublu faţă de cel al fetelor. Un fapt care pare a fi îngrijorător este acela că cele mai multe fete care au avut nevoie de îngrijiri medicale post consum de astfel de substanțe, au vârste cuprinse între 15 și 20 ani spre deosebire de băieți, unde consumatorii cei mai mulți care aparținut palierului de vârstă 21-29 de ani. Aproape în totalitate intoxicațiile cu substanțe psihedelice au avut ca și cauză consumul de etnobotanice. Potrivit datelor raportate de consumatori, calea cea mai folosită pentru administrarea acestor substanțe este cea inhalatorie (prin fumat).

Aproximativ 341 de pacienți în fiecare lună au avut nevoie de intervenția asistentului social pentru a se putea realiza externarea lor în condiții de siguranță.

\section{Concluzii}

Documentele elaborate de asistenții sociali din UPU Baia Mare, în perioada considerată pentru realizarea acestui studiu, arată că munca lor presupune 
activități numeroase, complexe, variate și solicitante și asta atât datorită diversității problemelor pe care asistenții sociali din aceste servicii trebuie să le rezolve.

Activitățile pe care le desfăşoară necesită stabilirea rapidă și continuă de contacte și colaborări atât cu pacienții și cu familiile acestora cât și cu alte persoane fizice implicate în îngrijirea bolnavilor și de asemenea cu serviciile sociale existente la nivelul comunității și diverse instituții publice cum sunt Poliţia, Evidența Populației, ANA etc.

Astfel asistentul social din departamentul de urgență asigură: externarea în condiții de siguranță a pacienților, facilitează accesarea serviciilor și beneficiilor sociale la care pacienții au dreptul conform legilor în vigoare, dirijează pacienții cu probleme sociale și/sau care nu constituie urgenţe medicale spre servicii mai adecvate situaţiei lor contribuind astfel la scăderea accesării serviciilor în UPU.

$\mathrm{Cu}$ toate beneficiile pe care această profesie le aduce, vorbim de o ocupație nouă și încă insuficient valorizată în România.

\section{Bibliografie:}

Anderson Eric Sorem,Lippert Suzanne,Newberry Jennifer (2016) - Adressing the Social Determinants of Health from Emergency Department, Western Journal of Emergency Department, Martie 2016;

Auerbach, C. \& Mason, S. (2010) - The Value of the Presence of Social Work in Emergency Departments, Social Work in Health Care, 49(4), 314-326;

Belea, Simion, (2014) The right to non-discrimination and equality of chances between women and men. în «Buletin Ştiinţific. Fascicula Filologie. Seria A», vol. XXIII/ Baia Mare 2014, Editura U. T. Press Cluj-Napoca, p. $363-$ 375 , ISSN 1583 - 1264,

Dziegielewski, S. (1998) - The changing face of health care social work: professional practice in the end of managed care. New York, NY. Springer Publishing Company;

Gordon JA.- Cost-benefit analysis of social work services in the emergency department: a conceptual model. Acad Emerg Med. 2001 Jan; 8 (1):54-60;

Moore L, Deehan A, Seed P, Jones R (2004) - Characteristics of frequent attenders in an emergency department: analysis of 1 year attendance data. Emerg Med J. 2009; 26:263-7 National Association of Social Worker www.naswdc.org/practice

Wrenn K, Rice N (1994) - Social-work Services in an Emergency Department: An Integral Part of the Health Care Safety Net, Academic Emergency Medicine, Volume1, Pages 247-253; 